Marquette University

e-Publications@Marquette

6-1-2011

\title{
On the Relative Accuracy of Discounting Based on Risk-Free and Risky Portfolios
}

Brian Brush

Marquette University, brian.brush@marquette.edu

Published version. Journal of Forensic Economics, Vol. 22, No. 1 (June 2011): 57-71. DOI. (C 2011 National Association of Forensic Economics (NAFE). Used with permission. 


\title{
On the Relative Accuracy of Discounting Based on Risk-Free and Risky Portfolios
}

\author{
Brian C. Brush*
}

\begin{abstract}
The degree of risk that should be incorporated into the net discount rate that is used to estimate the present value of future lost earnings has been the subject of controversy. While some forensic economists insist that a risk-free discount rate must be used, others have offered economic arguments that support use of a risk-adjusted rate. Historical simulation studies have found that, when the discount rate is based on risk-free or low-risk securities, the historical averages method of estimating present value is subject to large forecast errors due to significant changes in net discount rates over time. This study explores whether basing the discount rate on mixed portfolios of equities, intermediate-term government bonds, and Treasury bills might result in more accurate estimation. Using the historical averages method with data covering the period 1926-2008, results are generated for four mixed portfolios of varying degrees of risk, and these results are compared to the results obtained with Treasury bills, intermediate-term government bonds and long-term corporate bonds. The historical simulations do show that the mixed portfolios often provide more accurate estimates. These results should be of considerable interest to forensic economists who believe that some degree of risk should be incorporated into the discount rate.
\end{abstract}

\section{Introduction}

Many forensic economists base their net discount rates on the interest rates that can be earned on risk-free or relatively low-risk securities. U.S. Treasury bills are a popular choice as the basis for discounting, as they are generally considered to be the ultimate risk-free securities, free of both default risk and inflation risk. Treasury Inflation-Protected Securities (TIPS) are an alternative choice for "risk-free" discounting. Intermediate- and long-term Treasuries are also often used for discounting purposes, as they are generally considered to be free of default risk, although subject to inflation risk. High grade corporate bonds represent yet another step up in risk, as they carry some risk of default along with inflation risk.

The degree of risk, if any, which should be incorporated in the discount rate, has been the subject of controversy. The U.S. Supreme Court has rather clearly stated that "the discount rate should not reflect the market's premium

*Professor of Economics, Marquette University, Milwaukee, WI. 
for investors who are willing to accept some risk of default." (Jones \& Laughlin Steel Corp. v. Pfeifer 1983, emphasis added) This would not rule out use of either intermediate-term or long-term Treasury securities, which do protect against default risk, but presumably, would rule out the use of corporate bonds. However, two lines of economic argument have been offered against the use of a totally risk-free rate in cases of lost future earnings, and both of these suggest that the discount rate should be based on securities bearing some degree of default risk, not just inflation risk.

One line of argument focuses on the risk that, once the expected future earnings stream has been estimated, the actual earnings stream may deviate from the expected. Unless the future earnings stream to be discounted consists of certainty equivalents, or unless the decision-maker is indifferent to risk, the use of a risk-free discount rate would over-compensate the plaintiff. Therefore, the discount rate should incorporate a level of risk that is on par with the riskiness of the earnings stream itself. (See Jennings and Phillips, 1989; Margulis, 1991; Biederman and Baesemann, 1996; Henderson and Seward, 1998; Bell and Taub, 1999; Brush, 2003b.)

A second line of argument has been proffered by Breeden and Brush (2008), who suggest that, in the case of a large lump sum award intended to replace lost earnings for a long future period, the recipient can be expected to act as a "prudent investor," taking on a reasonable amount of risk in investing the lump sum for the long term. On this basis, they further suggest that the discount rate should incorporate a level of risk commensurate with the riskiness of the portfolio of securities that would likely be chosen by a prudent investor, a portfolio that might include equities as well as fixed-income securities.

The purpose of this paper is neither to support nor counter either of these lines of argument. Rather, the purpose is to examine whether basing the discount rate on the returns on a mixed portfolio of securities might be more or less accurate in estimating the correct lump sum award than is basing the discount rate on a relatively "risk-free" security. It is possible that estimates of present value might be improved if the discount rate were based on a mixed portfolio of risk-free, low-risk and risky securities such as equities. While the year-to-year returns on equities are clearly much more volatile than the yearto-year returns on risk-free securities, long-term average returns on mixed portfolios may be more stable than long-term average returns on risk-free or low-risk securities, given that returns on different asset classes may have countervailing cycles. If so, historical averages based on the returns on a mixed portfolio may more accurately estimate the lump sum necessary to replace the future lost earnings.

Admittedly, the results of this examination will be of little interest to the forensic economist who insists that the discount rate must be totally risk-free or that it must be completely free of default risk. However, with the acceptance of the idea that at least some degree of risk should be incorporated into the discount rate, it becomes a matter of some interest whether doing so might improve the accuracy of estimating future net discount rates and the present value of future lost earnings. 
In this study we use historical simulation to compare the forecast accuracy of the historical averages method of estimating the present value of future lost earnings when the discount rate is alternatively based on the returns on Treasury bills, intermediate-term government bonds, long-term corporate bonds, and four mixed portfolios consisting of varying proportions of equities, intermediate-term government bonds, and Treasury bills. We do find empirical support for the proposition that basing the discount rate on a diversified portfolio would have improved the accuracy of estimation in the past, although it is by no means certain that the same results would prevail in the future. The rest of this paper is laid out as follows: in Section II we describe our approach, data and computational methods; Section III then follows with the presentation of our primary results; Section IV explores whether the choice of labor earnings series affects the results; Section V examines the historical patterns behind the averages presented in Section III; finally, we close out the paper in Séction VI with some concluding comments.

\section{Approach, Methods and Data}

According to a recent survey, the historical averages method is the approach most widely used to estimate the present value of future lost earnings, with $43 \%$ of respondents using it. ${ }^{1}$ In this method, the net discount rate is derived as the approximate difference between the average interest rate and the average wage growth rate over some lengthy historical period. Unfortunately, historical simulation studies using risk-free or low-risk securities have demonstrated that this method often would have been highly inaccurate if used in the past, at least for long-term (20- or 30-year) losses. This was the finding of a major study that used interest returns on high grade corporate bonds (Schilling, 1985), and also of another major study that utilized interest returns on both Treasury bills and intermediate-term government bonds. ${ }^{2}$ (Brush, 2003a) These studies show that using a lengthy past period to estimate a net discount rate to be used to discount wage losses over a lengthy future period simply would not have worked well in the past due to significant movements in net discount rates over time (Brush, 2003a, 99-100).

\footnotetext{
'The second most widely used approach is the current rates method, in which the discount rate is based on rates prevailing at the beginning of the future loss period (Brookshire et al., 2009, p.18). Given the volatility of equity returns, it would clearly be inappropriate to base the discount rate on a portfolio that includes a significant proportion of equities while using the current rates method alone. However, there have been recent suggestions in the literature that combining the historical averages and current rates methods, while using Treasury bills, may work well (Cushing and Rosenbaum, 2006 and 2010). Although one could certainly combine historical averages using portfolios with current rates using Treasury bills, the current study focuses exclusively on the historical averages method.

2In the Schilling study (1985), which employed data on high grade corporate bonds covering 1900 82 , the average estimation error for 30-year forecasts using a variant of the historical averages method was $32 \%$. In the Brush study (2003a), which used data on Treasury bills and intermediateterm government bonds covering 1926-2001, the average estimation error with Treasury bills was $94 \%$ for 30 -year forecasts and $41 \%$ for 20 -year forecasts. Using the intermediate-term government bonds, the average estimation error was $69 \%$ for 30 -year forecasts and $40 \%$ for 20 -year forecasts.
} 
There is limited information available on how forensic economists actually use the historical averages method. In the survey referred to previously, $27 \%$ of the respondents used a past period that matches the length of the future period, while $53 \%$ indicated use of a fixed period that is independent of the worklife. To project for a 30-year earnings loss, the average length of the past period used was approximately 27 years (Brookshire et al., 2009, p. 19). In the absence of any further information on actual practice, we will use, for all 30year forecast periods considered, the average compound wage growth rate $(W)$ and the average compound rate of return on investment $(R)$ over the immediately preceding 30-year period to estimate the present value of future lost earnings. For each 20-year forecast period, we alternately use the $W$ and $R$ from either the immediately preceding 30-year period or the immediately preceding 20-year period for estimation. Again, our focus is on how the relative accuracy of the historical averages method might be affected by varying the riskiness of the investments on which $R$ is based.

The rate of return on investment $(R)$ in this study will be based on seven alternative investment options, as follows:

(1) $100 \%$ Treasury bills;

(2) $100 \%$ intermediate-term government bonds;

(3) $100 \%$ long-term corporate bonds;

(4) a portfolio consisting of $30 \%$ large-cap stocks, $30 \%$ intermediate-term government bonds, and $40 \%$ Treasury bills;

(5) a portfolio consisting of $40 \%$ large-cap stocks, $30 \%$ intermediate-term government bonds, and $30 \%$ Treasury bills;

(6) a portfolio consisting of 50\% large-cap stocks, 30\% intermediate-term government bonds, and $20 \%$ Treasury bills;

(7) a portfolio consisting of $60 \%$ large-cap stocks, $30 \%$ intermediate-term government bonds, and $10 \%$ Treasury bills.

These seven investment options are arranged from least risky (Treasury bills) to most risky (the 60-30-10 portfolio). Obviously, the mixed portfolios are only four of a potentially infinite number that could be used, which might include other investment options as well. However, they are sufficient in number and variety to shed light on the impact of portfolio riskiness on forecast accuracy.

The investment returns used in this study cover the period 1926-2008 and can be found in or calculated from data in Ibbotson (2009). These are matched with data on the U.S. manufacturing wage (Council of Economic Advisors, 2002 and 2009, Table B-47, and U.S. Department of Commerce 1975, Series D 802-810.). These data are used to calculated the compound average rate of return $(R)$ and the compound average wage growth rate $(W)$ for the designated historical periods, and the net discount rates $(N D R)$ are then calculated as

$$
N D R=\frac{1+R}{1+W}-1
$$


In all cases, the net discount rates calculated in this way are used to determine the estimated present value of the future earnings loss. These estimated present values are then compared to the actual present values that represent the actual lump sums that would have been required to replace the future lost wages, given the actual year-to-year investment returns and wage growth that prevailed during the periods for which the forecasts are made. For purposes of calculating both estimated and actual present values, it is assumed that investment returns are received and wages paid out at the end of each year, and that the injured party's wages would have increased at the same rate each year as the wages of the average worker. All calculated awards are based on a base annual loss of $\$ 1,000$, as measured in the year just prior to the first year of the future loss period.

\section{Results}

Part A of Table 1 shows the results when 30 years of past data are used to project for 30-year future losses. Given that the data cover the period from 1926 through 2008 , there are a total of 24 rolling 30-year future periods to consider, ranging from 1956-1985 through 1979-2008. For each of the seven investment options previously described, the table reveals, under "direction of error," the number of cases of over-compensation $(+)$ and under-compensation $(-)$ that would have resulted, as well as the maximum over-compensation (a windfall to the plaintiff), the maximum under-compensation (a shortfall for the plaintiff), the mean percent error (the mean of the absolute values of the percentage deviations of estimated from actual present values) and the mean award ratio (the mean of the ratios of estimated to actual present values). The mean percent error is a measure of accuracy, indicating how close, on average, the estimates are to the actual present values. Since the mean percent error can be affected by extreme values, additional indicators of accuracy can be found in the final two columns, which display the number of cases (out of 24) in which the relative error was $<=20 \%$ and the number of cases in which the relative error was $<=10 \%$. The mean award ratio is a measure of bias, the average extent to which the estimates over- or under-compensate the plaintiff. ${ }^{3}$

The results with both Treasury bills and intermediate-term government bonds in Part A are very poor, consistent with the results previously reported in Brush (2003a). (Compared to that earlier study, the results now being reported utilize seven more years of data, so there are seven more cases.) For Treasury bills, there is over-compensation in every case, with a mean award ratio of 1.91, indicating a high degree of bias over these time periods. There is a very large mean percent error of $91 \%$, and not a single case of a relative error $<=20 \%$. For the government bonds, the outcomes are very similar, and there is just one case of a relative error $<=20 \%$. Long-term corporate bonds perform

${ }^{3}$ This layout is similar to that presented in an early historical simulation study by Dulaney (1987). It should be noted that, if all estimation errors are in the same direction, the mean \% error and the mean award ratio will appear to be redundant. However, with errors in both directions, this is not the case. For example, if half of the estimates are $50 \%$ too high and half are $50 \%$ too low, the mean $\%$ error will be $50 \%$, but the mean award ratio will be 1.00 , indicating no bias. 
somewhat better, with a mean percent error of $68 \%$, and with seven cases of errors $<=20 \%$.

The results with all four of the mixed portfolios in Part A are much better than the results with Treasury bills or government bonds for every measure of accuracy and bias, and all four also perform much better than the corporate bonds. The 50-30-20 portfolio appears to perform best overall, although just slightly better than the $40-30-30$ and $60-30-10$ portfolios. For the $50-30-20$ portfolio, the incidences of over- and under-compensation were almost equal in number $((13+, 11-)$ with a mean award ratio of 1.11 . The mean relative error was $20 \%$, and $75 \%$ of the cases showed a relative error $<=20 \%$, with $46 \%$ showing a relative error $<=10 \%$.

Table 1

Estimated vs. Actual Present Values

A. 30 Years Back, 30 Years Forward (24 Cases)

\begin{tabular}{|c|c|c|c|c|c|c|c|}
\hline $\begin{array}{c}\text { Investment } \\
\text { Option }\end{array}$ & $\begin{array}{c}\text { Direction } \\
\text { of Error }\end{array}$ & $\begin{array}{c}\text { Maximum } \\
\text { Windfall }\end{array}$ & $\begin{array}{c}\text { Maximum } \\
\text { Shortfall }\end{array}$ & $\begin{array}{c}\text { Mean \% } \\
\text { Error }\end{array}$ & $\begin{array}{c}\text { Award } \\
\text { Ratio }\end{array}$ & $\begin{array}{c}\text { Error } \\
<=20 \%\end{array}$ & $\begin{array}{c}\text { Error } \\
<=10 \%\end{array}$ \\
\hline Treasury Bills (90) & $24+, 0-$ & $132 \%$ & -- & $91 \%$ & 1.91 & 0 & 0 \\
\hline Intermediate Govt. & $24+, 0-$ & $142 \%$ & -- & $81 \%$ & 1.81 & 1 & 0 \\
\hline LT Corp Bonds & $20+, 4-$ & $165 \%$ & $25 \%$ & $68 \%$ & 1.64 & 7 & 5 \\
\hline Portfolio 30-30-40 & $24+, 0-$ & $90 \%$ & -- & $33 \%$ & 1.33 & 7 & 2 \\
\hline Portfolio 40-30-30 & $20+, 4-$ & $85 \%$ & $7 \%$ & $22 \%$ & 1.21 & 16 & 12 \\
\hline Portfolio 50-30-20 & $13+, 11-$ & $81 \%$ & $19 \%$ & $20 \%$ & 1.11 & 18 & 11 \\
\hline Portfolio 60-30-10 & $7+, 17-$ & $77 \%$ & $28 \%$ & $22 \%$ & 1.03 & 15 & 8 \\
\hline
\end{tabular}

B. 30 Years Back, 20 Years Forward (34 Cases)

\begin{tabular}{|l|c|c|c|c|c|c|c|}
\hline $\begin{array}{l}\text { Investment } \\
\text { Option }\end{array}$ & $\begin{array}{c}\text { Direction } \\
\text { of Error }\end{array}$ & $\begin{array}{c}\text { Maximum } \\
\text { Windfall }\end{array}$ & $\begin{array}{c}\text { Maximum } \\
\text { Shortfall }\end{array}$ & $\begin{array}{c}\text { Mean \% } \\
\text { Error }\end{array}$ & $\begin{array}{c}\text { Award } \\
\text { Ratio }\end{array}$ & $\begin{array}{c}\text { Error } \\
<=20 \%\end{array}$ & $\begin{array}{c}\text { Error } \\
<=10 \%\end{array}$ \\
\hline Treasury Bills (90) & $34+, 0-$ & $64 \%$ & -- & $45 \%$ & 1.45 & 2 & 0 \\
\hline Intermediate Govt. & $34+, 0-$ & $145 \%$ & -- & $51 \%$ & 1.51 & 4 & 1 \\
\hline LT Corp Bonds & $24+, 10-$ & $266 \%$ & $18 \%$ & $61 \%$ & 1.58 & 13 & 11 \\
\hline Portfolio 30-30-40 & $30+, 4-$ & $89 \%$ & $4 \%$ & $28 \%$ & 1.28 & 18 & 14 \\
\hline Portfolio 40-30-30 & $23+, 11-$ & $93 \%$ & $15 \%$ & $29 \%$ & 1.24 & 18 & 14 \\
\hline Portfolio 50-30-20 & $19+, 15-$ & $97 \%$ & $24 \%$ & $32 \%$ & 1.20 & 16 & 10 \\
\hline Portfolio 60-30-10 & $17+, 17-$ & $101 \%$ & $31 \%$ & $35 \%$ & 1.17 & 12 & 6 \\
\hline
\end{tabular}

C. 20 Years Back, 20 Years Forward (44 Cases)

\begin{tabular}{|l|c|c|c|c|c|c|c|}
\hline $\begin{array}{l}\text { Investment } \\
\text { Option }\end{array}$ & $\begin{array}{c}\text { Direction } \\
\text { of Error }\end{array}$ & $\begin{array}{c}\text { Maximum } \\
\text { Windfall }\end{array}$ & $\begin{array}{c}\text { Maximum } \\
\text { Shortfall }\end{array}$ & $\begin{array}{c}\text { Mean \% } \\
\text { Error }\end{array}$ & $\begin{array}{c}\text { Award } \\
\text { Ratio }\end{array}$ & $\begin{array}{c}\text { Error } \\
<=20 \%\end{array}$ & $\begin{array}{c}\text { Error } \\
<=10 \%\end{array}$ \\
\hline Treasury Bills (90) & $42+, 2-$ & $88 \%$ & $13 \%$ & $38 \%$ & 1.37 & 14 & 2 \\
\hline Intermediate Govt. & $39+, 5-$ & $142 \%$ & $37 \%$ & $43 \%$ & 1.38 & 9 & 2 \\
\hline LT Corp Bonds & $34+, 10-$ & $289 \%$ & $47 \%$ & $53 \%$ & 1.44 & 14 & 7 \\
\hline Portfolio 30-30-40 & $33+, 11-$ & $114 \%$ & $17 \%$ & $39 \%$ & 1.34 & 16 & 12 \\
\hline Portfolio 40-30-30 & $31+, 13-$ & $129 \%$ & $27 \%$ & $44 \%$ & 1.34 & 14 & 4 \\
\hline Portfolio 50-30-20 & $30+, 14-$ & $144 \%$ & $40 \%$ & $48 \%$ & 1.35 & 10 & 5 \\
\hline Portfolio 60-30-10 & $28+, 16-$ & $159 \%$ & $42 \%$ & $54 \%$ & 1.35 & 7 & 5 \\
\hline
\end{tabular}

Part B of Table 1 presents the outcomes when 30 years of past data are used to project for 20 years of future losses. There are 34 rolling 20 -year future periods to consider, from 1956-1975 through 1989-2008. Once again, all of the 
mixed portfolios perform much better than either Treasury bills or government bonds, although the differences are not as pronounced as with the 30-year forecasts. With Treasury bills, there is again over-compensation in every case, with a mean award ratio of 1.45 , indicating a high degree of bias. There is a very large mean relative error of $45 \%$, only two cases of a relative error $<=20 \%$, and no cases of a relative error $<=10 \%$. The results with the government bonds are very similar. In contrast, the mixed portfolios provide much better balance between over- and under-compensation, with mean award ratios much closer to unity. The mixed portfolios also have much lower mean relative errors and many more cases of relative errors $<=20 \%$ and $10 \%$, respectively. For example, the 40-30-30 mixed portfolio has a mean relative error of $29 \%$, with 18 (out of 34) cases resulting in a relative error $<=20 \%$ and 14 cases resulting in a relative error $<=10 \%$. About two-thirds of the cases result in over-compensation, with a mean award ratio of 1.24 . The $30-30-40$ and $50-30-20$ portfolios produce very similar results to those of the $40-30-30$ portfolio. The $60-30-10$ portfolio is slightly less accurate, but provides the best balance between over- and undercompensation, with 17 cases of each and the lowest mean award ratio of 1.17. As for corporate bonds, their performance is in some respects much better than Treasury bills or intermediate-term government bonds, as they have many more cases of relative errors $<=20 \%$ and $10 \%$. However, the corporate bonds have a higher mean percent error and a higher mean award ratio than either of the Treasury securities, due largely to the extreme swing in the total returns on corporate bonds in the late 1970s and early 1980s. The simple average of the annual total returns (which include capital gains and losses) over the fiveyear period 1977-1981 is -1.31 , while the simple average of the annual total returns over the five-year period $1982-86$ is 23.12 . This dramatic shift resulted in several periods of greatly over-estimated present values, including a maximum windfall of $266 \%$, as shown in Table 1, Part B.

As an alternative to using 30 past years to forecast for 20 future years, we show in Part $\mathrm{C}$ of Table 1 the results from using 20 past years for the 20-year forecasts. There are now 44 future periods to consider, ranging from 1946-65 through 1989-2008. Using 20 past years instead of 30 generally provides modest improvement in the performance of the Treasury bill, Treasury bond, and corporate bond options, while it worsens the performance of the mixed portfolios, so the mixed portfolios no longer have a clear advantage. The modest difference in the performance of the fixed-income securities between Part B and Part C of Table 1 may be happenstance, but the superior performance of the mixed portfolios in Part $\mathrm{B}$ compared to Part $\mathrm{C}$ has a rational explanation. Given that the portfolios contain equities, the most volatile of the asset classes, the use of a longer (30-year) rather than a shorter (20-year) historical period can be expected to do a better job of smoothing the fluctuations, resulting in better forecasts over any length of future loss period. This is likely to be less important for the fixed income investments, given their usual lesser volatility.

In any case, when a 20-year historical period is used for the 20-year forecasts, most of the investment options produce very similar results. The 30-3040 portfolio and Treasury bills appear to be the best choices, with the 30-30-40 portfolio having an edge over Treasury bills because it produces many more 
instances of relative errors $<=10 \%$ (12 for the portfolio vs. only 2 for Treasury bills) and because it provides better balance between over- and under-estimation. But comparing the results from Parts $B$ and $C$ of Table 1, it appears that the most accurate method of estimating the present value of 20 -year future losses is with one of the mixed portfolios while using 30 , rather than 20 , years of past data.

\section{The Choice of Earnings Series}

As noted earlier, this study makes use of the U.S. manufacturing wage series in calculating both estimated and actual present values. This is the only labor earnings series available that extends back over the entire time period covered in this study. Ideally, the labor earnings series used would provide broader coverage of the economy and include employer-provided fringe benefits as well as wages. Fringe benefits were minimal prior to World War II, but became increasingly important as a share of total compensation during the war and thereafter. No doubt for this reason, the index of compensation per hour in the non-farm business sector has been available since 1947. (Council of Economic Advisors, 1994, Table B-47 and 2010, Table B-49) Over the period 19472008, the U.S. manufacturing wage grew at the compound average annual rate of $4.48 \%$, while the compensation index grew at the rate of $5.40 \%$. Given this significant difference, it would be useful to determine whether our results might be significantly different if the compensation index were used instead of the manufacturing wage.

Using data from the 1947-2008 period to compare the results with the manufacturing wage and the compensation index, we can get results for only two time periods when using a 30-year historical period to forecast for a 30 year future loss, only 12 time periods when using a 30 -year historical period to forecast for a 20-year future loss, and just 22 time periods when using a 20 year historical period to forecast for a 20-year future loss.

It is very clear from the results of these comparisons that the choice of the earnings series makes only a minimal difference in results. For example, consider some of the results using 20 past years for 20 future years. Using Treasury bills as the investment vehicle along with the manufacturing wage, all 22 cases result in over-compensation, with a mean percent error of $28 \%$, a mean award ratio of $1.28,10$ cases with errors $<=20 \%$, and one case with errors $<=10 \%$. Using Treasury bills with the compensation index instead, all 22 cases again result in over-compensation, with a mean percent error of $27 \%$, a mean award ratio of $1.27,11$ cases with errors $<=20 \%$, and two cases of errors $<=10 \%$. Using the $30-30-40$ portfolio with the manufacturing wage, we get 16 cases of over-compensation and six cases of under-compensation, a mean percent error of $48 \%$, a mean award ratio of 1.43 , seven cases of errors $<=20 \%$, and five cases of errors $<=10 \%$. Using the $30-30-40$ portfolio with the compensation index instead, we get 16 cases of over-compensation, six cases of under-compensation, a mean percent error of $46 \%$, a mean award ratio of 1.42 , seven cases of errors $<=20 \%$, and five cases of errors $<=10 \%$.

While the choice of earnings series makes little difference, it is interesting that the data just summarized indicate that the use of Treasury bills resulted 
in noticeably lower mean percent errors and mean award ratios than the 3030-40 portfolio over the 22 most recent periods, in contrast to the very similar results for these two investment options for the entire set of 44 periods covered in Table 1, Part C. This suggests that an examination of the historical time patterns of the estimation errors with each investment type is in order.

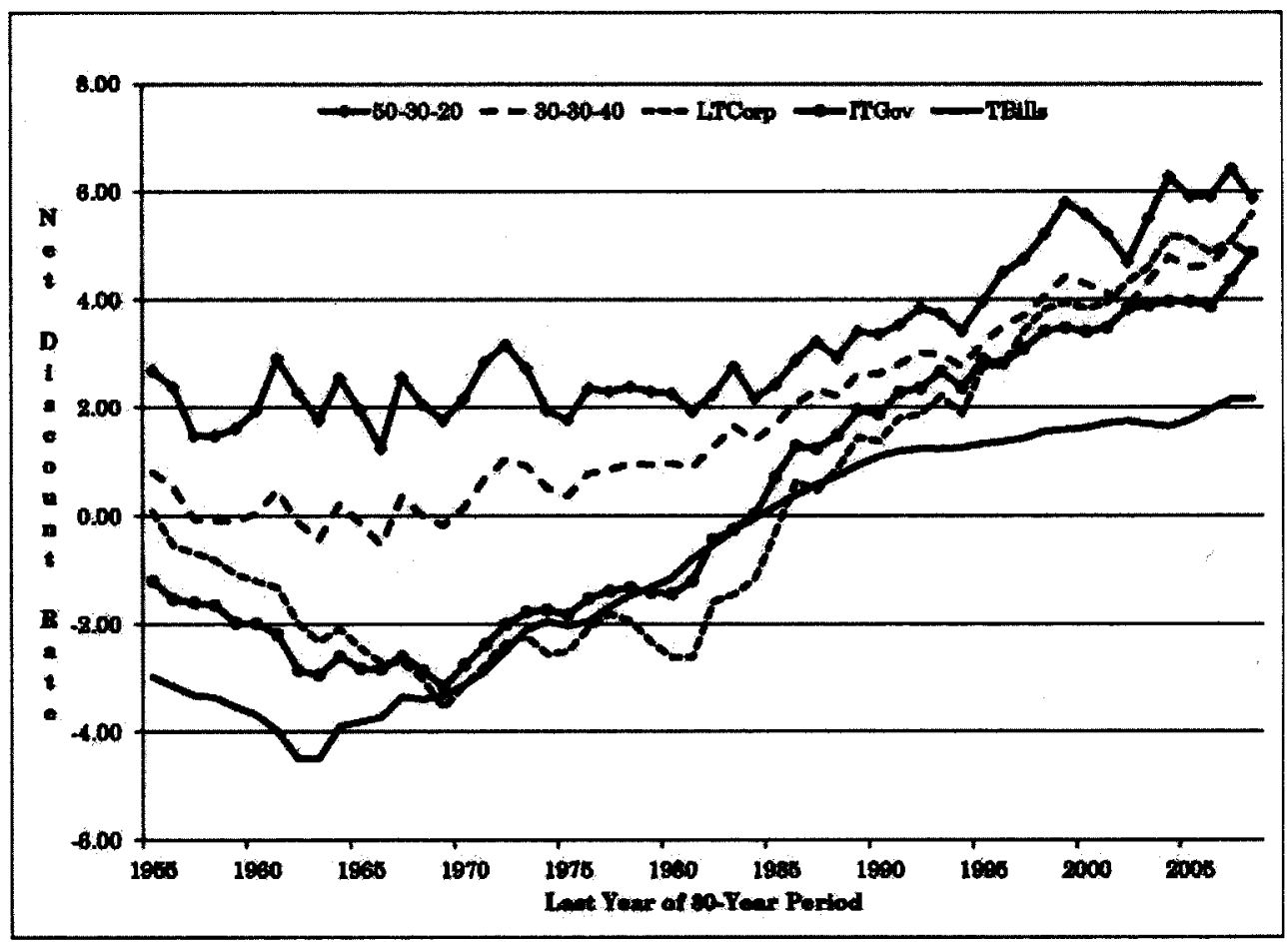

Figure 1. Trailing 30-Year Net Discount Rates

\section{Further Discussion - Historical Patterns}

Regardless of how they are calculated, net discount rates do vary significantly over time. The relatively strong tendency towards over-compensation that can be observed in the results shown in Table 1 can only be the result of a general rise in net discount rates over the historical period covered in this study. Figure 1 displays trailing 30-year net discount rates using five of the seven investment options (the 40-30-30 and 60-30-10 mixed portfolios have been omitted to reduce clutter) along with the manufacturing wage. For example, for the year 1955, the figure shows the average net discount rate for the period 1926-55 for each of the five investment options. Now, if 30 past years ending in 1955 are used to estimate for the 30-year future period 1956-85 and the trailing 30-year net discount rate in 1985 is significantly higher (lower) than it is in 1955, significant over- (under-) compensation will result. Simi- 
larly, if 30 past years ending in 1955 are used to estimate for the 20-year future period 1956-75 and the trailing 20-year net discount rate in 1975 (see Figure 2 for the 20-year rates) is significantly higher (lower) than the trailing 30 year net discount rate is in 1955 , significant over- (under-) compensation will result.

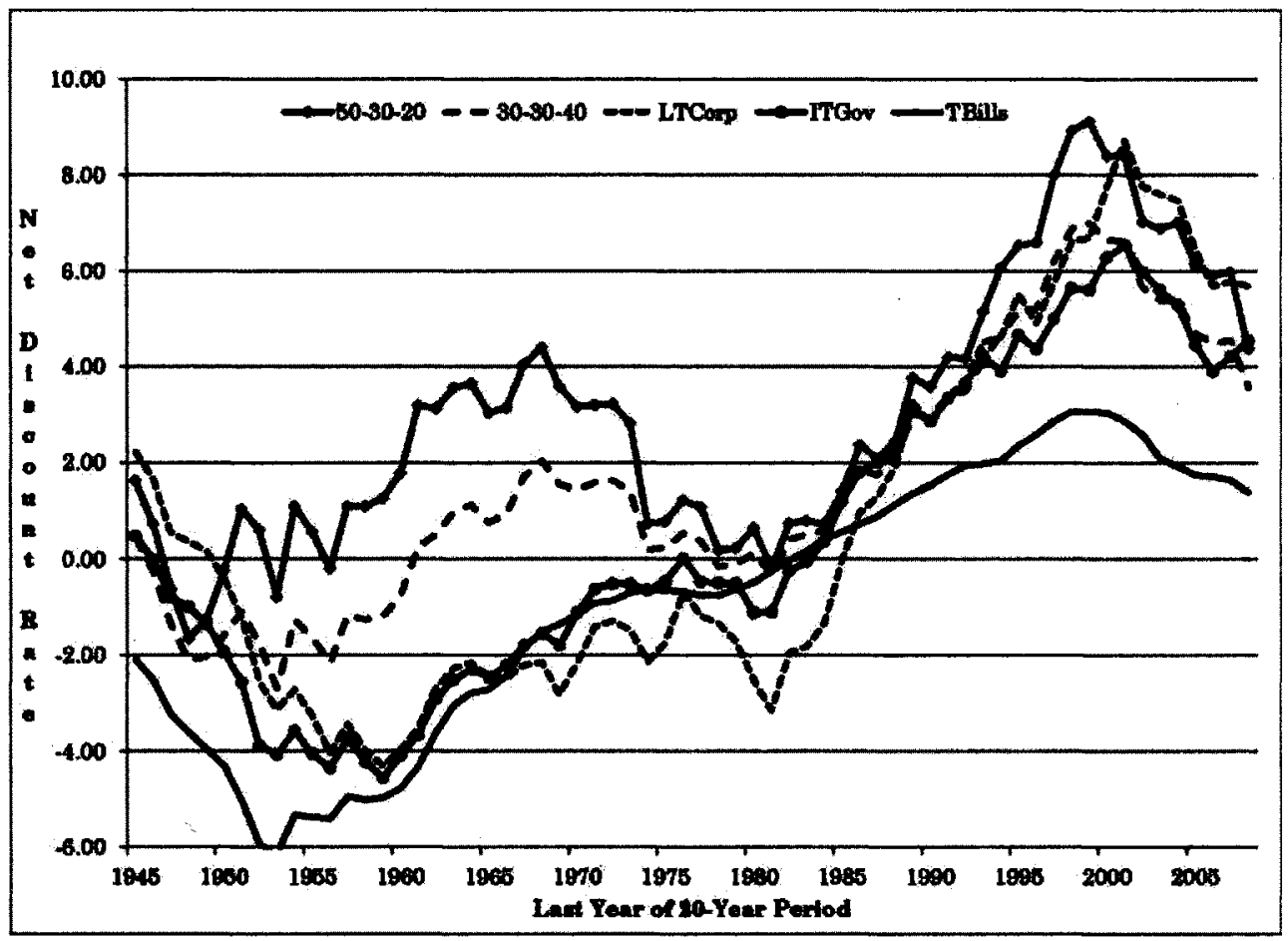

Figure 2. Trailing 20-Year Net Discount Rates

In Figure 1 there is a general upward movement in the trailing 30-year net discount rates for all five investment options, although the 50-30-20 portfolio has a relatively high degree of stability over approximately the first 30 years of the 54 years covered, resulting in its superior performance in Table 1, Part A. The trailing 20-year net discount rates displayed in Figure 2 are much less stable, and with the exception of Treasury bills, the trailing net discount rates show extremely sharp increases for approximately 20 years beginning around 1980. Following this, all the 20 -year rates have begun to come down, which if sustained could ultimately lead to a lengthy period of years during which $20-20$ forecasts result in under-compensation. A comparison of Figure 1 and Figure 2 does suggest that, in general, using 30 years instead of 20 years to average the net discount rate does lead to smoother patterns over time which would likely lead to more accurate estimates using the historical averages method. 


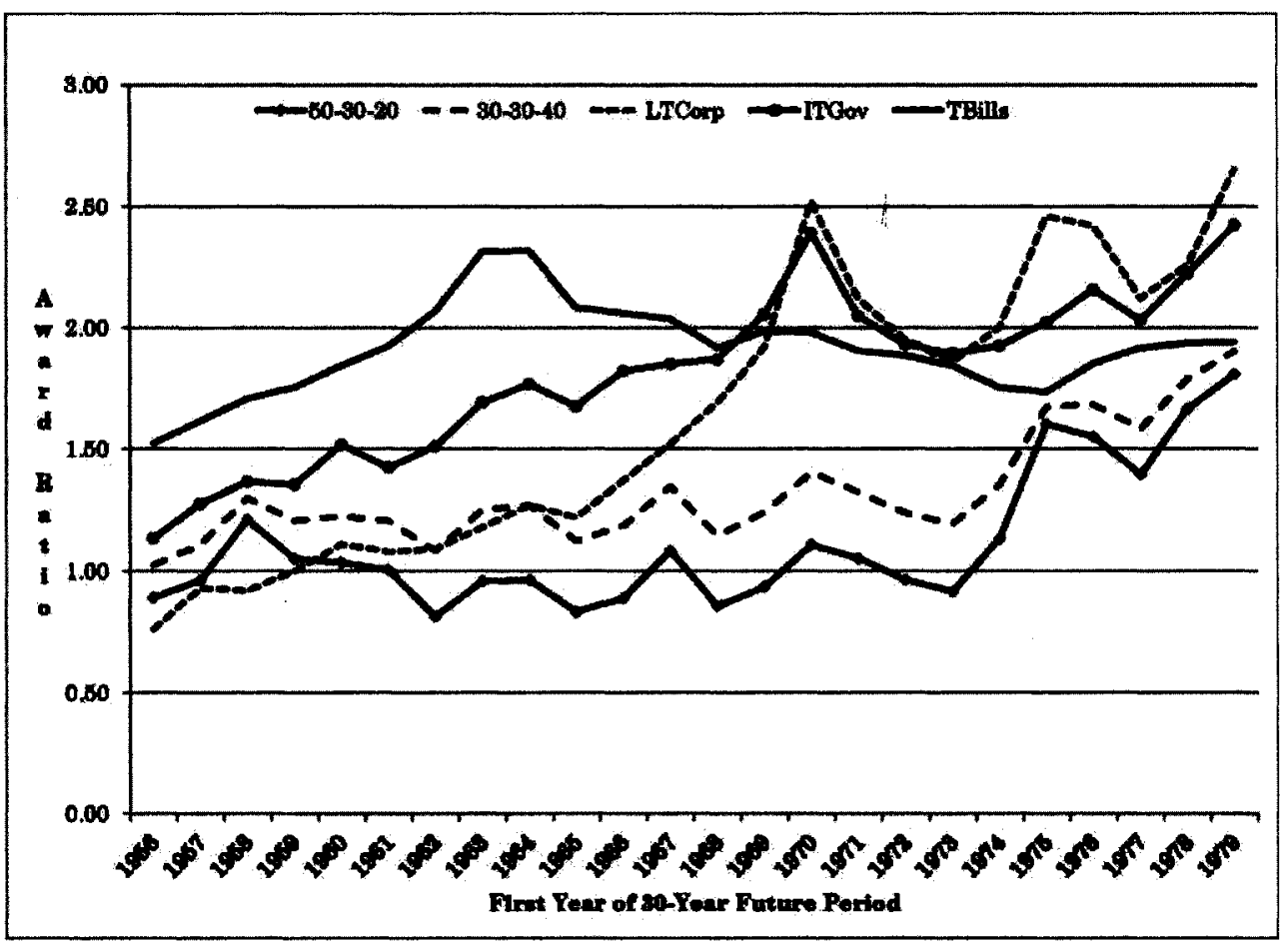

Figure 3. Ratios of Estimated to Actual Present Values, 30-30

Figure 3 shows how the award ratios varied through time when 30 past years of data were used to estimate 30-year future losses. The 50-30-20 portfolio produced award ratios relatively close to unity throughout the first $19 \mathrm{fu}$ ture time periods considered until an abrupt uptick occurred for the last five future periods from 1975-2004 through 1979-2008. But even during these last five periods, this investment option resulted in award ratios closer to unity than all of the other investment options. The 30-30-40 portfolio consistently overcompensated, as previously shown in Part A of Table 1, but Figure 3 reveals that it did not produce the many extremes of overcompensation found with Treasury bills, intermediate-term government bonds, and long-term corporate bonds. So, while the averages in Part A of Table 1 hide the fluctuations that occurred over time, Figure 3 does indicate that the two mixed portfolio options were rather consistently superior to the three fixed income options throughout the time covered in this study.

The time pattern of the award ratios when 30 past years were used to forecast for 20-year future periods is shown in Figure 4. Here, the two mixed portfolios generally stay closest to an award ratio of unity, consistent with the results in Part B of Table 1. However, what the averages in Part B don't reveal is that, for the last eight (out of 34) 20-year future periods beginning in 1982 , Treasury bills worked best. Also noteworthy is the huge spike in the forecast 
errors using long term corporate bonds in the late 1970s and early 1980s, which inflated the mean percent error and mean award ratio for this investment option. This is the result of the abrupt upward shift in the total returns on corporate bonds described earlier.

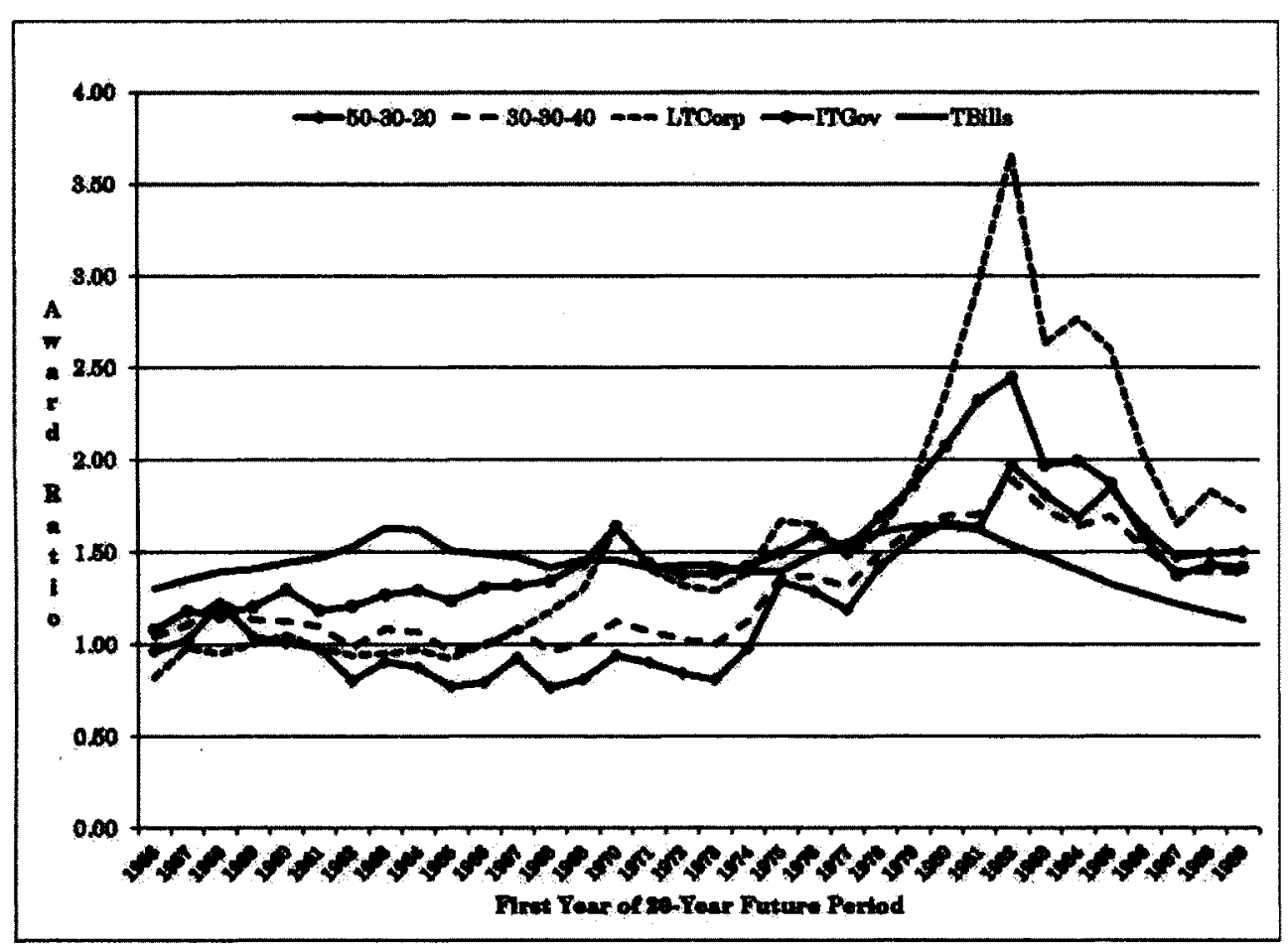

Figure 4. Ratios of Estimated to Actual Present Values, 30-20

Figure 5 displays the time pattern of the award ratios when 20 past years were used for 20-year future losses. In discussing the results in Part $\mathrm{C}$ of Table 1 , we observed that the overall results were very similar with most of the investment choices. Again hidden behind those averages is the large spike in forecast errors with long-term corporate bonds and the emergence of Treasury bills as the best estimator for the most recent forecast periods.

After considering the historical patterns behind the overall averages presented in Table 1, what can we reasonably conclude? First, there is no reason to believe that net disceunt rates generally will continue to rise into the future. Just as there has been a long historical period of generally rising net discount rates, it is certainly possible that this could be followed by a long period of generally falling net discount rates. As seen in Figure 2, the trailing 20-year net discount rates began to fall approximately 10 years ago, and if this trend continues, the historical averages method is likely to begin to consistently unders- 
tate future losses, regardless of the investment option employed. Second, whether net discount rates generally rise or fall in the future, it seems likely that, as in the past, the use of a longer rather than a shorter historical period on which to base the net discount rate will produce more accurate estimates of future losses, especially with the mixed portfolios. Third, there was no single investment option which, when used as the basis for discounting, produced more accurate forecasts of present value for all periods examined. Fourth, however, over the long historical period considered in this study, mixed portfolios produced more stable long term (30-year) net discount rates than did the kinds of investment choices on which the net discount rate is usually based (e.g., Treasury bills or intermediate-term government bonds), leading to more accurate forecasts of present value in most cases.

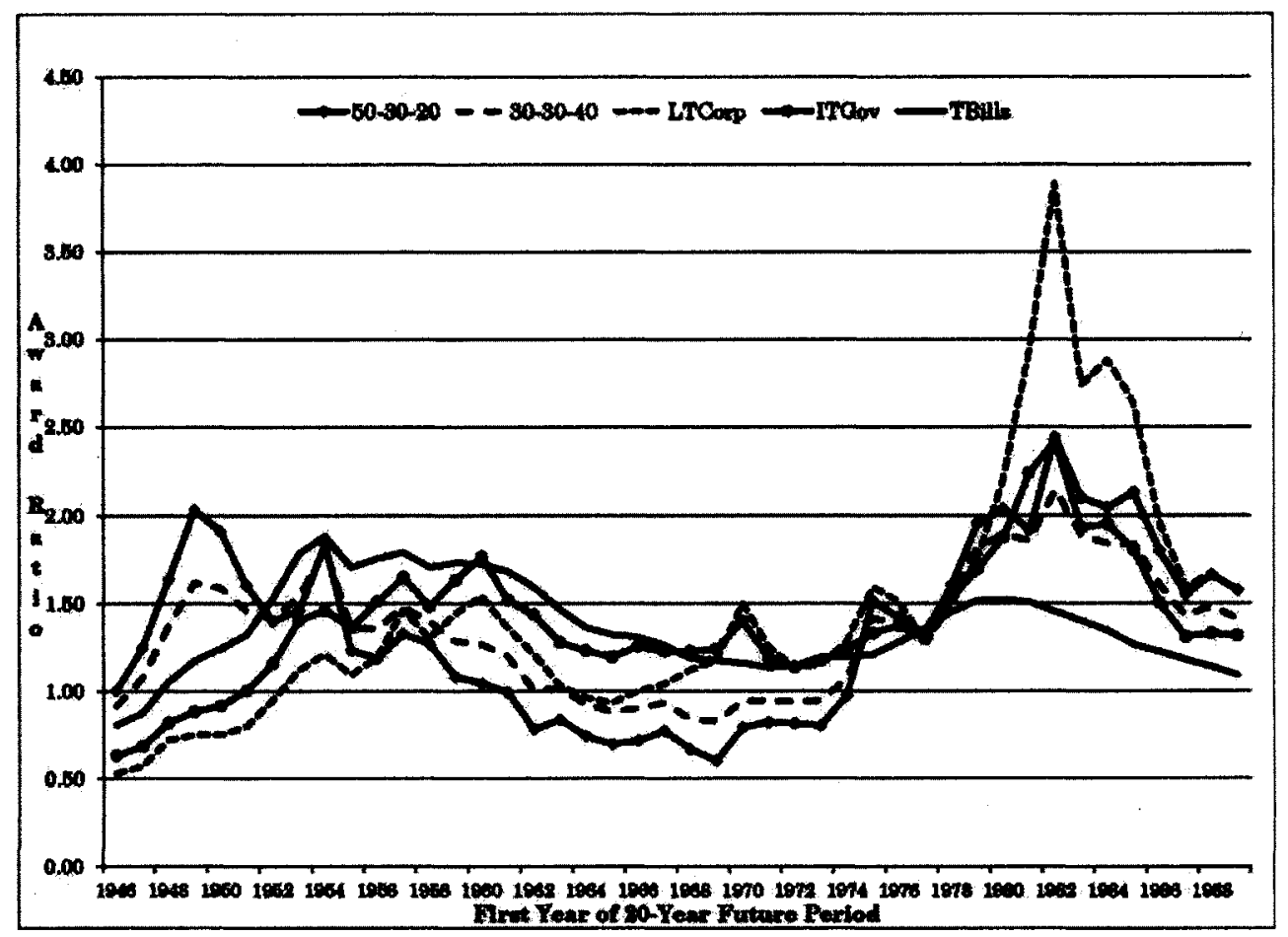

Figure 5. Ratios of Estimated to Actual Present Values, 20-20

Of course, there is no guarantee that mixed portfolios will out-perform the fixed income portfolios in the future. However, in choosing a method to estimate the present value of lost future earnings, it is certainly relevant to consider how accurate the method would have been had it been used in the past. And for any economist who uses the historical averages method and believes 
that risk should be incorporated in the discount rate, our results provide some support for doing this.

\section{Concluding Comments}

The degree to which risk should be incorporated into the net discount rate used to estimate the present value of future lost earnings is the subject of controversy. While it is often argued that only a "risk-free" or low-risk discount rate should be used, economic arguments have been offered in opposition to this position. Some have argued that the discount rate should reflect the riskiness of the earnings stream itself. Others have argued that the discount rate should reflect the riskiness of the portfolio of securities that the recipient of a large lump sum award would prudently choose to invest in. If one accepts either line of argument, it becomes untenable to hold on economic grounds that a risk-free discount rate should be used. It then becomes a matter of considerable interest whether use of a "risky" rather than a "risk-free" discount rate might improve the forecast accuracy of the historical averages method, which has been shown in previous studies to be subject to very large errors in estimating the present value of future lost earnings.

This paper does not address the question of what is the proper degree of risk to incorporate into the discount rate. However, the historical simulations of the historical averages method described in this paper do show that, for many of the time periods covered by the data, several alternative portfolios of varying degrees of risk that include a mix of equities, government bonds, and Treasury bills clearly out-performed either government bonds or Treasury bills alone in estimating the actual lump sums needed to compensate the plaintiff for future lost earnings over 20- and 30-year future periods. To the extent that any of these portfolios represent the forensic economist's view of the proper degree of risk for the discount rate, it is reassuring to know that the historical experience suggests that the use of such portfolios in conjunction with the historical averages method may also result in more accurate estimates of present value.

\section{References}

Bell, Edwaird B., and Allan J. Taub. 1999. "Some Issues Concerning Risk Adjustments in Damage Calculations." Litigation Economics Digest, 4(2):153-55.

Biederman, Daniel K., and Robert C. Baesemann. 1996. "Risk-Free vs. Risk-Adjusted Discount Rates: A Comment." Journal of Forensic Economics, 9(1):45-47.

Breeden, Charles H., and Brian C. Brush. 2008. "The Plaintiff as Victim and Investor: Prudent Investing and the Calculation of Economic Damages.” Journal of Legal Economics, 14(3):15-41.

Brookshire, Michael L., Michael R. Luthy, and Frank Slesnick. 2009. “A 2009 Survey of Forensic Economists: Their Methods, Estimates, and Perspectives." Journal of Forensic Economics, 21(1):5-34.

Brush, Brian C. 2003a."The Past as Prologue: On The Accuracy of Using Historical Averages in Discounting Future Lost Earnings to Present Value." Journal of Legal Economics, 13(1):81-107. 
2003b. "Risk, Discounting, and the Present Value of Future Earnings." Journal of Forensic Economics, 16(3):263-274.

Council of Economic Advisors. 1994, 2002, 2009, 2010. Economic Report of the President, Washington, DC: U.S. Government Printing Office.

Cushing, Matthew J., and David I. Rosenbaum. 2006. "Historical Averages, Unit Roots and Future Net Discount Rates: A Comprehensive Estimátor." Journal of Forensic Economics, 19(2):139-159.

2010. Predicting Net Discount Rates: A Comparison of Professional Forecasts, Time-series Forecasts and Traditional Methods." Journal of Forensic Economics, 21(2):147-171.

Dulaney, Ronald A. 1987. "An Historical Simulation Approach to the Present Value of Future Earnings." Journal of Forensic Economics, 1(1):37-48.

Henderson, James W., and J. Allen Seward. 1998. "Risk Aversion and Overcompensation from the Risk-Free Discount Rate." Journal of Legal Economics, 8(2):25-32.

Ibbotson SBBI 2009 Classic Yearbook. 2009. Chicago: Morningstar.

Jennings, William P., and G. Michael Phillips. 1989. "Risk as a Discount Rate Determinant in Wrongful Death and Injury Cases." The Journal of Risk and Insurance, 56(1):122-127.

Jones \& Laughlin Steel Corp. v. Pfeifer, 462 US 523 (1983).

Margulis, Marc S. 1992. "Compensatory Damages and the Appropriate Discount Rate." Journal of Forensic Economics, 6(1):33-41.

Schilling, Don. 1985. "Estimating the Present Value of Future Income Losses: An Historical Simulation 1900-1982." The Journal of Risk and Insurance, 52(1):100-116.

U.S. Department of Commerce, Bureau of the Census. 1975. Historical Statistics of the United States: Colonial Times to 1970. Bicentennial Edition, Washington, DC: U.S. Government Printing Office. 